\title{
Processing (Post)humanism, Mediating Desire: Technology in the Works of Three Border Playwrights
}

\section{Paul Fallon}

As new technologies have been more visible, accessible, and affordable in the U.S.-Mexican border region, particularly as compared to other parts of Mexico, electronic media hold increasing importance there. Though critics have not directly associated high-tech change with theatrical expression on the border, the maquiladoras that have made Tijuana the television manufacturing capital of the world, the music and videos from the Nortec collective, and the numerous blogs by border authors attest to the technological pervasiveness in the region over the last several decades. ${ }^{1}$ So, too, do the military technologies of heat and motion-detector sensors, infrared night vision, biometrics and air surveillance the U.S. Border Patrol uses to guard national space. ${ }^{2}$ The works Cibernauta: Cómo vivir atrapado en la red (1999) by Francisco J. López, Generación Atari (2001-02) by Juan Ríos Cantú, and Teoría y práctica de la muerte de una cucaracha (sin dolor) (1997) and La habitación (2004), both by Bárbara Colio, all foreground electronic media and their consideration. ${ }^{3}$ These four works closely link fascination with new media to sexual desire and examine the power relations involved, addressing the shifting human-machine interactions that scholar Donna Haraway features in her "Cyborg Manifesto." She declares that, whereas previously the relationship between the organism and the machine has been "a border war," now "we are all... theorized and fabricated hybrids of machine and organism; in short, we are cyborgs" ("Cyborg" 150). By contrast, these four plays show less an embrace of than an anxiety about and critique of new technologies. Rather than proffer any wholesale condemnation or celebration, the works emphasize concrete limits, focus on human desire, and pose human-machine interaction as an open question. They signal that any cyborg society or posthumanism that arises would come about 
through a recursive social process that requires feedback and, particularly through their staging, they invite audience participation in such processing. ${ }^{4}$

These four works have gained the recognition of awards, productions and publications, but have received only limited critical attention. Cibernauta won the CAEN-UABC-ICBC-IMAC theatrical creation competition in 2000 and debuted in Tijuana the same year (López 7). Ríos, perhaps more celebrated as an actor, has had several of his plays produced and, with Generación Atari, is the only Mexican dramatist in ten years to have a work presented in the commercial theater circuit in Mexico City (Quijano). The most well-known playwright of the three, Colio, has more than twenty dramatic works published and has had productions and translations of her work appear in several countries (Postma 147). La habitación was awarded the 2002 Premio Estatal de Literatura de Baja California, while Teoria, included in three different published play collections and produced numerous times, has inspired experimental video art by Enrique Beggar and Héctor Ruiz (Trujillo Muñoz 257; Almela). Colio has also won a number of prestigious national and international awards, including the 2009 Premio Nacional de Dramaturgia de Bellas Artes and the 2004 Premio Internacional María Teresa León in Spain.

Despite these playwrights' successes, critics have devoted little more than short reviews to the works. Some studying theater on the border have focused more on themes popularly associated with the region, such as migration, cultural identity, maquiladoras, and drug trafficking (Beardsell; Partida "La cultura regional" and "El Teatro del Norte"). Others have discussed the effects of new technologies on changing border situations and expression, but have done so primarily in metaphoric fashion, using terms such as realidad virtual and dramaturgia hipertextual to theorize avantgarde theatrical techniques (Galicia; Mijares). By contrast, the present essay looks at the concrete treatment of new media, placing it amongst the themes rooted in the region and examining how the works portray humantechnological interaction. ${ }^{5}$

The association of sexual desire and new media plays a central role in the four works. In Cibernauta, the title character Héctor's obsession with computers and virtual reality causes him to break up with his partner, Electra. The intervention of their mutual friend, Angel, reveals the trio's past love triangle, and the conflict intensifies when the men discover nude photographs of Electra on the internet. Another love triangle forms the nexus of Teoria. While the unnamed protagonist tapes a video message for his lover, he reveals that filming their adulterous, homosexual relationship contrib- 
uted to his lover's divorce, subsequent heart attack, and semi-paralysis. The work closes with an onstage video showing the fatal reactions to the taped message. ${ }^{6}$ La habitación portrays a man and woman struggling to communicate through a webcam site. As she, Ella, vacillates about continuing, the man, Él, does not want to leave the screen for a moment, but when he does, his urge to return quickly moves him to violence. Finally, Generación examines how four children in a border town become more aware of the world around them after one receives an Atari videogame as a gift. While Lila and Oscar negotiate a mutual attraction through game playing, Oscar competes with Roberto both to win games and Lila's affection. Jano, struggling with early homosexual desire and a strict upbringing as a Jehovah Witness, plays few video games, but as a young man, makes a documentary about the machine's effect on their lives. ${ }^{7}$ In all these works, an interest in and the characters' interactions with electronic technologies strongly influence their desired relationships.

The present essay examines how the works frame a social landscape in the process of changing the way such relationships are mediated in order to engage the evolution of that process. I first focus on the stage directions from each text and my notes from a July 14, 2005, performance of Generación Atari - directed by the playwright himself as part of a three-month run at Foro Shakespeare in Mexico City-in order to show how the works visually and aurally present human-technological interactions as an open question for the audience. I then examine the way the works depict elements of that process as feeding into both emerging practices and existing exclusions that generate the dramatic stakes involved. The plays relate the technologies to an increased social openness regarding diverse expressions of sexuality, even as existing hierarchies, relationship difficulties, and tragic events signal problems with the technological mediation of desire. Haraway argues that facing the mixed feelings about the changes arising from shifts in technology requires "not sorting consciousness into categories of clearsighted critique... versus 'manipulated false consciousness,' but subtle understanding of emerging pleasures, experiences, and powers with serious potential for changing the rules of the game" ("Cyborg" 173). The works analyzed here consider game-changing possibilities through their exploration of not only the developing pleasures, experiences, and powers Haraway mentions, but also of related limits and interruptions. As the works negotiate these aspects of budding high-tech culture, however, they do so more with an idea of critiquing human-machine relations than with an idea of defending the "sujeto humanista/letrado" from an inevitable evolution toward a 
specific idea of posthumanism (Brown 20). ${ }^{8}$ Emphasizing the ongoing, interactive nature of the transformations involved, the works contribute to the process of imagining, and thereby affecting, those developing relations.

\section{The Fourth Wall as Interactive Screen: Processing Human-Technology Relations}

The staging of each play invites the audience to participate in affecting those relations as well by using the fourth wall as an interactive screen. While, to a degree, actors and staging always convey messages and provoke audience response, these plays foreground the mediation of screens between actors and the public, soliciting reflection and reaction. This framing offers a distance that enables critique. Yet even as the works offer critiques, they do not characterize human-machine interaction as any fixed set of relations, but rather as a process to be determined.

Cibernauta stages a conflict between an obsession with virtual technology and desire. The didascalia lists a number of electronic devices to have onstage, all of which "están contectadas al CPU de la computadora, cruzan el escenario de lado a lado y van a conectarse directamente a un televisor que se encuentra en el otro extremo" (9). Even the modest dining room harbors a movie poster from The Matrix. The multimedia objects strewn about the stage surround Héctor, the internet-surfing protagonist, simultaneously making him a focal point and foregrounding his obsession. This setting also reflects the way that Héctor has marginalized Electra, a woman that he had desired so strongly at one time; the stage directions describe nothing as hers, and later Héctor confirms everything present has to do with him and his obsession (23). The visual presentation further emphasizes this conflict of human desire and a fixation on technology. At the moment that Electra reveals Ángel had left for graduate studies when she, pregnant, had most needed him, Héctor comes in wearing "un ridículo traje cibernáutico" (45). The suit physically manifests Héctor's separation from others and his connection to technology. His insensitivity to others becomes nearly complete after a short circuit leaves him unable to perceive odors, tastes, and colors.

The monitor screen facing the public offers another focal point, one that frames the play with an overbearing sales pitch for computer technology. The stage directions call for the screen to play an "informático muy a doc [sic] a la realidad virtual" (11) to open the first scene, and again to close each of the five following $(18,37,54-55,61)$. The sound bites presented optimistically promote computing technologies with advertising language, affirming, for example, that “¡Las tecnologías interactivas están creando un 
nuevo estilo de vida!" (11). Each message follows scenes of tension specifically related to technology, giving the television screen the last word on the topic. After the discovery of Electra's nude photos, the screens announce that "[d]elante del monitor, la gente tiende a ser más desinhibida y espontánea" (37). Following Héctor's incapacitation, a message concedes that, although computers seem to democratize relationships, "sin embargo, se sufre una mayor tendencia al aislamiento" (55). Finally, after Electra's suicide, the last message intones that "contaremos con una serie de cuerpos artificiales trabajando para nosotros a distancia" (61). The timing, placement, and content of these messages emphasize a common optimistic discourse about electronic technologies, as well as the disjunction between that discourse and the struggles that the characters face as a result of an obsession with the technologies. The repeated glib celebration of high tech culture after Electra's death signals the power of the discourse and critiques it. These foregrounded televised ads also offer ironic contrasts to the performed events and establish a critical distance between the drama and the audience.

For its part, Teoria presents a small space where the electronic equipment stands out, marking the first division of the many that characterize the work. The lone speaking character films his own message in the small, ordinary apartment living room, where "los muebles antiguos de la casa contrastan con la moderna televisión, que ocupa el sitio más importante de la sala, y con una cámara de video montada en su tripié" (77). His choice to film the video rather than speak directly to his lover, who sleeps in the next room, comes to mark the large emotional gulf separating them. At the same time, the small apartment, which perhaps once offered a quiet place for intimacy, has become a jail cell of sorts, cutting the pair off from the world, especially now that the sick lover is so limited in his movement. Similarly, the medium of video, which seems to be a means for bringing them together intimately at the beginning of the work, later underlines the pair's isolation. The couple does not show their love for each other publicly, so the videos serve as a memento, a sort of pleasurable proof for themselves of the existence of their own relationship. Even as the filming marks a distance between the man and his lover, by addressing the onstage camera located between him and the audience as if he were speaking to his lover, the performer puts the audience in his lover's place. This positioning raises the question of the larger public's own acceptance or rejection of homosexuality, which is so often marginalized. Thus, the play uses the smaller space and the technology both to emphasize isolation and question the breach of marginalization. 
This dynamic of both establishing and questioning alienation deepens with the second "cuadro," titled "la práctica," in which a television screen presents all onstage action. Set later in the same room, the stage directions call for light to come only from that screen, which shows the consequences of the previous cuadro (91). While a dead man lies in a pool of blood, filming continues even as the protagonist shoots himself; the image goes dead, and the light finally fades to black. Though the images end after the protagonist kills himself, the entire video replay occurs after the suicide, since the only light comes from the television itself. While the staging of the first cuadro presented actions within the already limited space of the apartment room, the representation of the tragic events solely through the even smaller frame of the television underscores the characters' isolation from each other and the audience. The screen facing the audience also raises questions regarding their own continuing interaction with the technology before them, as it simultaneously separates them from the protagonists' pain and brings that suffering into view.

In Habitación, the visual setting connects new electronic technologies with ideas of space and personal relations that are in the process of definition, a process in which the audience participates, seeing the pleasures and difficulties involved. The synopsis accompanying the work describes a room that is: "dos en una. Espacios geográficamente distantes pero simultáneos en el tiempo... aunque el público no lo descubra desde un principio" (2). The stage directions add that "la estética de esta única habitación parte del punto de vista de él [el protagonista], situación que debe ser descubierta por el espectador poco a poco" (4). Thus, when the first scene opens with both characters on stage and Él speaks, apparently directing himself and reacting to Ella, the audience has to figure out the pair's actual physical and emotional relationship. ${ }^{9}$ Visual clues offer conflicting evidence: though the pair appears to share a room, Ella sleeps under only sheets, while Él shivers wearing a sweater and a scarf (4-5). Él is watching her live webcam transmission from a location at some distance from her, yet the stage directions note that physical presence of screens and cameras onstage are unnecessary (4). Given this situation and staging, in that traditional stage positioning would have the actors at least partially facing the audience, the fourth wall would then act as a screen that mediates the interaction between the two principal characters. Initially lacking definitive signs of such a screen, the audience, much like the characters, must orient themselves within the new technologically fraught situations in order to sense the mediation involved. 
As the work progresses, the various scenes note new forms of contact and closeness made possible through electronic technologies, but also emphasize separations. Play has a role in the process, for, though some physical distance separates the pair, onstage Él and Ella share a bowl of cereal. Further, though the two perform "diálogos [que] se dirán de una manera simultánea" (17), their communication goes only one way-Ella cannot hear or see Él. The shared bowl prop and the timing of the characters' lines insinuate togetherness, emphasizing how the internet connects, intimately yet incompletely, even as the audience must attend to clues in order to understand that a space divides the two. Difficulty, misunderstandings, and frustration arise, too: frantic to return to his computer, Él attacks an insistently rule-following cashier who struggles with her scanner; engrossed in a personal phone call, the supermarket manager does not hear the cashier's calls for help; and the security guard misses the assault, too, as he plays a videogame. After the violence, each of the two coworkers appears seated before a tape player in a police investigation room, disconcerted, defensive and alone. The play closes with Ella alone, trying to contact Alma, while the audience hears "un enjambre de sonidos," that the text presents visually as a mix of messages, channel changes, raspy recordings and jingles, together titled "la verdad" (39). The scenes present different spaces and relationships as characters direct themselves more through machines and less directly towards each other, offering new ways of imagining intimacy and play, but also contributing to already existing communication problems and leading to deep frustrations and violence. The last swirling mass of sounds reiterates the process of adjusting that underlies the staging from the beginning. If earlier in the play the audience has had to orient themselves in order distinguish the distinct, distant spaces that the characters inhabit despite their apparent proximity on stage, this final moment breaches the fourth wall to include the audience, engulfing them in the same dark space. To have this performed moment become "the truth" as it is titled, the audience must tease out that truth from amongst a jumble of noises.

Generación foregrounds a maturing sense of play and desire that develops within and reflects upon changing society and technology. The stage presents a park with two swings, a slide, and a seesaw, while later noting "la copa suspendida" of a tree (21) - in the performance I saw the tree crown appeared as a projected image floating in the background. This setting emphasizes the rupture associated with the new generation, a rootlessness matched by the lack of any parents physically appearing in the work. ${ }^{10}$ The arrival of the Atari game represents a substantial shift from the space 
of the playground and the stage directions have the game light up the scene and take up space. Thus, when Oscar opens the box "su rostro se ilumina con una suave luz que proviene de ahí" and the box "se convierte en una pequeña mesa sobre la cual vemos un monitor de TV y un juego de ATARI" (6). The performed work, however, exchanged a small monitor for a giant fourth wall video screen; when the actors played games, they mimed joystick motions while looking directly at the audience. Through the different games, the characters reveal something of themselves. Jano, for example, plays with Lila's Barbie when she leaves it behind, hides it when the other boys come around, and then gets an erection when they wrestle each other. Roberto does well in all games but Frogger, in which the player has to cross over boundaries. And Oscar loves Space Invader, which makes him feel like a Border Patrol agent stopping illegal crossers. Yet having the characters face the audience to play their videogames places the audience itself in the location of those games as the children concentrate and interact with what they see. As the play examines traditional social mediation (in school and church, for example) alongside the mediation of electronic games, this staging questions the role of the individuals attending the performance. The positioning thus problematizes the interaction of children with the audience before them (and vice versa), and also signals the way that the games themselves affect what might otherwise be face-to-face dialog.

At the end of the work, when the characters meet again as adults at the old playground, human-technology relations continue to be featured. Jano's documentary about "el impacto que tuvo el videojuego en nuestras vidas" allows him some control in framing the past events (39). The staging foregrounds that mediation, as the characters that are filming position themselves between the audience and those speaking. In addition, Roberto, a seeming failure in the Mexican school system, has found success as a videogame designer. Even as the last words and images of the play register Oscar's death and absence, the positive changes noted in the play and the ludic element of videogames themselves contribute to the relatively generous attitude toward technology that Generación conveys. Focusing on the transition from childhood and later retrospection as adults, the work more strongly features a process of adjustment in dealing with new phenomena, signaling the temporary nature of these changes and the possibilities of alternatives.

Taken together, the staging of these works contributes to the critiques of technology as a means of mediating desire and, in foregrounding the recursive process of changing human-technological relations, invites 
audiences to participate in that process. Each mise en scene emphasizes an atmosphere of consumerism that engulfs these relations, the isolation and alienation that current use of new technologies worsens, and the communication problems that result, all of which interfere with connections of desire and bonding. As the concluding segments of each work punctuate their critiques by foregrounding technological mediation - the persistent virtual reality ads in Cibernauta, the lone television set of Teoria, the swarm of machine-filtered voices in Habitación, and the documentary camera of Generación - they feature alterable recordings, and thus call for input for future recordings, for feedback in changing human-technological relations. The emphasis in each play on a framing activity accentuates possibilities of agency and change. It also calls attention to scale, as the social interactivity of the imagined divide of the theatrical fourth wall offers a sharp contrast with the more focused, individuated interactivity of the screen's smaller, physical divide in new media. Thus, the works not only take up the desire for connection as a theme, they value and call for it, even as they critique the technological mediation of different forms of desire. As part of that critique, the plays highlight various elements and set the dramatic stakes involved in that processing of human-machine relations. They depict the reception of new phenomena and the continuation of existing conditions, and note pleasures, problems and dangers that arise around the relationships mediated by electronic technologies.

\section{New Times: Emerging Experiences and Pleasures}

These plays emphasize the newness of those technologies by associating them with suggestive dates, temporal disjunctions, and a process of learning and/or adaptation. In Cibernauta, interspersed televised messages announce the arrival of a new generation. The actions of Generación occur days before a principal character's birthday, then just before Christmas, while La habitación occurs during Mardi Gras and Teoría takes place during the anniversary of the couple. Taken together, these temporal settings link new developments related to electronic technologies with a potential impetus for celebration.

The foregrounding of negotiation, adaptation, and learning also signal transformations that the new technologies represent. When Héctor dons a virtual reality suit in Cibernauta, he discovers both wonder and suffering. In La habitación, human-machine operations can interfere with communication, worsen conflicts, and require time to understand. The cashier's inability to use her cash register and optical reader contributes to her death, as 
Él has no patience for her slowness. Further, as noted earlier, the synopsis and stage directions specifically involve the audience in coming to sort out the role of the new media. In Teoria, while the protagonist adeptly arranges a video camera, a monitor, and lighting to film his message, he reveals that he first gained interest in videos from his lover. The childhood friends of Generación clearly depict a technological learning process as they discover how to play the Atari and interpret the importance of those games. In addition, as adults, they come to effect the use of technologies, as Jano becomes a director and Roberto a game designer. In all of the works, the characters have to learn how to coordinate material bodies with the images represented. The process of learning and adapting human-technology relations signals both the newness of the phenomena and the possibility of change.

Yet along with these symbolic dates and learning experiences, the works also highlight the effects of the time gap that arises with new media, a breach that temporally separates an activity from its recording and its eventual presentation. Of course, such gaps occur through the medium of writing as well (as Jacques Derrida and Homi Bhabha discuss in depth), but the works associate the disjunctions linked to new technologies with other personal and social separations. In Cibernauta, the nude photos of Electra taken years earlier spur old, chauvinistic jealousies in her two ex-partners, and the three characters clash violently about their earlier relations. While much of La habitación emphasizes the "real" time (and altered space) of streaming webcams, the final images offer a strong contrast. The stage going black and the sounding of a jumble of recorded messages emphasizes isolation in form and content. With no senders or receivers apparently present, the darkened, empty space underscores the depersonalization of the messages, which echo information related to the protagonists' failure to connect. Teoria similarly emphasizes the emotional resonance of the temporal break, as the protagonist records his video message even though the intended recipient, his lover, lies nearby. His choice to convey the message indirectly takes advantage of the separation of the time gap between action, image and reception, clearly marking the emotional gulf that so sharply contrasts with the intimate space both characters share. Generación first presents the four protagonists as children in the $1980 \mathrm{~s}$, then, in the antepenultimate scene, the characters film each other speaking as adults and Jano announces his work on a documentary. This clearly marks the interval between childhood behaviors and recording and presenting those experiences as adults. Noting that gap while featuring the role of videogaming foregrounds the framing involved in the focus on the later, larger consequences of those initial, 
youthful experiences with media and each other. In each work, the temporal gap hints at other separations and informs the critiques presented.

The plays also feature pleasures involving interpersonal connections that arise with the new technologies, gratifications that contribute to what Brian McNair characterizes as a "democratization of desire" (11-12). By this, McNair means a broader access to a range of sexual expression and the increased visibility of a more diverse, pluralistic sexual culture. These works offer a similar perspective, depicting pleasures that include elements of play, freedom, escape, and appropriation. In Cibernauta, Héctor prefers the imagined interactions offered by the screen and keyboard: "(Teclea) Sería muy emocionante conocerte, aunque la verdad tengo algo de miedo... La verdad, yo prefiero no conocerte jamás. Esta clase de relación cibernaútica creo que es más real y sincera" (19). The internet allows him the possibility of fantasy unfettered by responsibility to a specific person, even as his desire for a relationship remains. Though, as Héctor says later, the internet offers a means to not live alone and unconnected, he clearly values the freedom to imagine as he wishes. With the difficulties all three characters have had in their more traditional relationships, electronic media assuages Héctor's fear of face-to-face interaction while supporting his continuing hopes for controlled connections.

In La habitación, Ella also desires connection, even without knowing whether or not another person observes her onscreen: " $¿$ Te gustaría jugar a la pelota conmigo?/Te espero./Podríamos.../ Quisiera.../ verte a los ojos. Mirarte. / (Sonriente) Conocerte como tú a mí" (30-31). These hopeful lines combine the gratifications of playing and of initiating a more intimate bond with that of the more equitable interchange of seeing her counterpart ("como tú a mí"). She plays with appropriating visual control and directing it back at her observer/voyeur, while her smile underlines the ludic pleasure. The protagonist of Teoría also enjoys the play of the visual, as he declares to the camera, and thereby to his lover: "Me contagiaste tu adicción a los videos, a las televisiones. Una aquí, otra más grande en la recámara.... Yo había pensado en escribirte algo, pero viéndola [sic] bien esto es mejor, es más divertido. Así me ves tú, y yo creo que te veo por aquí" (80). Video offers a distinct enjoyment for the two, a diversion, and a reflective appreciation of their otherwise marginalized homosexual relationship. ${ }^{11}$

By contrast, Lila, in Generación, expresses her appreciation for the Atari video game that serves as a means of avoiding abuse in her home: "Papá. Su respiración. Papá. La gran mano izquierda. Entra. ¡Papá! Su mano derecha tapa mi boca.... No me gusta. No, no. Me duele. No me gusta.... 
Jugar con mis amigos me gusta. Oscar. Me gusta el juego de Oscar. El Atari. La casa de Oscar. Su nombre. Los ojos de Oscar" (19). Her monologue mixes her yearning to escape domestic molestation with her desire for Oscar, specifically as mediated by videogames. In each case, technology provides outlets for desire, empowering new venues for a diverse eros.

The plays, then, emphasize novel experiences arising with and through electronic technologies, specifically as they relate to desire and increased openness. Other powers that these technologies might offer, such as curing ills, building infrastructure, or improving access to social goods, receive little serious attention, appearing occasionally as unrealistic ads or distant, inflated ideals. Hector's virtual reality suit presents the most advanced creation amongst the works; cutting edge technology like artificial intelligence does not make an appearance, out of reach in the settings portrayed. Instead, characters encounter new media and machines as innovations that demand adaptation and that offer novel means by which to connect with others, more freedom in making such associations, and the ability to challenge established restrictions.

\section{Out with the Old? Exclusions, Hierarchies, and Ghosts}

Yet the works also suggest that the new technologies support existing hierarchies - often informed by particular conceptions of masculinitythat exclude, marginalize and threaten, sometimes fatally. The boys in Generación nearly make the Atari an experience for males only. They do not let Lila play much; she only has the opportunity to do so alongside Oscar. The nude images of Electra on the internet and Héctor and Ángel's reactions to them in Cibernauta reflect the chauvinistic attitudes of those characters and society more broadly, and point to the way the internet contributes to such attitudes. When the two men discuss the value of cyberspace, they focus primarily on the ubiquitous pornography and sex-related sites that objectify women. In that vein, Electra's photos symbolize not only both men's desire, but also their lack of consideration for her, as she had agreed to have the pictures taken to pay for an abortion of a fetus that either man could have helped create. The work portrays these websites as fueling such exploitation. Though by contrast, La habitación displays Ella's assertion of her own desires, she herself also recognizes the objectification involved in the webcam sites. Frustrated by the one-sided nature of the experience, she calls her presumed viewer "enfermo," and, baring her chest, asks "¿Qué es lo que esperas? ¿Eh? ¿Es esto?” (12). Despite her resistance, she, too, realizes the 
invasive nature of the voyeurism. The technology in Teoria similarly provides possibilities of visual enjoyment, but the individualized camera supports an emphasis on exclusionary public appearances separate and distinct from private practices. Thus the unnamed lover has exposed the protagonist to the pleasures of home filming, but denies his own homosexuality publicly, trying to maintain a hollow heterosexual image even after a divorce. The personal video camera enables this division of public and private image, allowing for the continued marginalization of homosexuality. Though a variety of sexual behaviors gain consideration through technology in the four works, power still operates through a system of permits and prohibitions that limits the democratization of desire.

The works also broadly link restrictions that arise as part of new electronic cultures to those associated with the existing hierarchies of written technology and a humanistic sujeto letrado, and criticize those shared restrictions. Generación signals problems of access. Roberto, from a poor family, does badly in his classes but excels with videogames (he plays them ably, then designs them as an adult). However, he learns about the technology through his wealthier friend Oscar, whose father buys the game in the U.S. While the play lampoons as inflexible and excessively nationalistic the Mexican schooling that marginalizes Roberto, it also signals that access to technology-afforded by money and the openness to opportunity that the U.S. represents - and not the technology itself, contributes to Roberto's later success. Both lettered and digital subjects receive support from infrastructures that favor the wealthy and can act as barriers to the poor. In $L a$ habitación, while the imperfect mediations of electronic devices often make interactions between individuals difficult, the lone example of writing, a report by a security guard, offers similar problems. The guard uses halftruths and formal-sounding, legalistic language to cover his incompetence, negligence, corruption, and jealousy, to alter facts, and to criticize the dead victim herself: "Se determinó que el ataque, crimen y robo perpetrado a mano armada preparado con alevosía y ventaja, a claras luces se manifiesta como crimen de móvil pasional dado que el presunto sostenía relaciones de tipo sexosas [sic] con la víctima" (23). The robbery he mentions is one he committed himself, the preparation a self-serving invention, and the sexual relations a projection of his own jealousy and insecurity. The unseen partner in Teoria also underscores the continuity between the literate elite and the technologically savvy. Before the offstage partner showed the protagonist how to use video cameras, he first introduced a world of books, citing texts 
in order to impress. Yet the protagonist now realizes his partner's empty parroting of literature constitutes the smooth exterior to the private interior of personal cameras:

me encontré con tus mismas palabras pero escritas por otros. No, no es que me importe; finalmente tú me las enseñaste.... El "gran señor" me había elegido a mí para descubrirme el mundo.... que has llenado de tus cosas, de tus discos, tus televisiones... Un mundo con cuatro paredes y una puerta que me devuelve a ti, girando a tu alrededor... esperando el premio de fin de semana cuando mandas a la familia con las tías a Ensenada. (83-84)

The public man of letters has used the privacy of electronic technologies with ease to keep the protagonist enclosed, alone, and invisible. Cibernauta brings the digital and the lettered subject even closer together. While the work condemns the way Héctor ignores Electra and focuses instead on cyberspace, the pair's relationship only came about after Ángel had similarly turned from her to continue his university studies. Rather than bringing about a positive change, the cibernauta repeats the errors of el hombre letrado in more extreme fashion. Similarly, the works taken together less celebrate digital technologies for breaking with reading culture than they critique those technologies for continuing exclusions of the lettered city.

In addition, phantasmal figures appear in all of the works to register those excluded, marginalized, or hurt by the contemporary uses of digital technology. They enact what Avery Gordon affirms of ghost stories more broadly, that they concern "exclusions and invisibilities" and "not only repair representational mistakes, but also strive to understand the conditions under which a memory was produced in the first place, toward a countermemory, for the future" $(17 ; 22) .{ }^{12}$ The nude internet images of Electra in Cibernauta appear like ghosts from the past, but it is the abortion she had (which spurred those very photos) that haunts, marking the emotional separations between her and Angel. When Héctor's obsessions with virtual reality, cyberspace, and the objectification of others create deeper separations, Electra's suicide creates another spectral memory of the bonds lost due to engendered fixations. In La habitación, while the guard gives his self-serving false testimony, his radio interrupts him repeatedly, echoing the voice of the murdered cashier: "Su radio emite señales de interferencia, entre lo confuso del ruido se escucha una voz entrecortada que dice 'seguridad, seguridad" (23). This causes him to lose his composure and violently turn the impotence he felt about the victim ("La muy...mmmmmme ignoraba") 
toward the radio, first smothering, then bashing it (24-25). The ghostly radio calls further establish the conflict between technological interactions and emotional relations that the work criticizes, while clearly favoring the latter. The protagonist of Teoria condemns his partner's duplicity and exhorts him to act ("Viviste con todo y no te decidiste por nada. Decide ahora tu muerte"), even as he affirms that both of them are "fantasmas" (89). The second "frame" of the work confirms their ghostly status, as a video displays images of the pair's actions even as their dead bodies lie at the back of the stage. The couple's images survive them to haunt a public idea of masculinity and heterosexual marriage, even as the private technology aids in maintaining the marginalization of homosexuality. In Generación, the topic of ghosts arises from Oscar's explanation that, by eating a flashing light, the avatar in the game Pacman can gobble up ghosts that had once been pursuers. The children then speak of spirits they know of; one turns off lights, while another died because gas was left on overnight. The "death" of Oscar's avatar in the game interrupts this discussion, as he laments, "ya no me dieron otra vida" (15). This interchange foreshadows drug traffickers later killing the boy and, finally, when the other protagonists reunite as adults, Rober, Atari box in hand, asks where Oscar is, "en ese momento un columpio vacío se empieza a mover muy lentamente" (40). This spectral reminder of Oscar and the spirits the children speak of mark both losses resulting from and some expression of resistance to new technology and also signal caution in the face of an incessant consumerism that is exemplified by the Pacman figure. The works thus concern themselves with those who are excluded, harmed, or unseen even in these highly-surveilled cybernetic times, haunting the future with countermemories of phantasms.

The ghosts also reflect a larger anxiety about death in the dramatic works. In each, the past frames the technology of the present and existing divisions and frictions worsen as they are mediated through technological forms. In this way, the works echo Haraway regarding the gravity of the situation: "Who cyborgs will be is a radical question, the answers are a matter of survival" ("Cyborg" 153). Each of the works presents at least one violent death related to the new electronic media. Rejected by her technologically obsessed partner, Electra kills herself in Cibernauta. In La habitación, Él strangles the cashier to return to his webcam obsession. The tragic pair of Teoría commits suicide, as their personal videos become evidence in a divorce case. In Generación, Rober's uncle betrays Oscar's drug trafficking father. Rober wins the Atari, emigrates, and becomes a computer 
programmer, and both Oscar and his father die. These tragic events highlight the concerns the works express about technology. Thus, even as the works relate new technologies to an increased social openness regarding more diverse expressions of sexuality, they also link these technologies to continuing structures of inequality and marginalization and signal the limits involved in the technological mediation of desire. The specter of death that arises in each work forcefully raises, as Haraway suggests, the nature of machine-human relations as a process involving high stakes still to be determined.

\section{Processing, Not Concluding: Reproduction of Desire versus Desire for Reproduction}

The shadow of death reflects concerns about surviving. Critics such as Haraway, Mary Anne Doane, and Robin Truth Goodman have pointed out that anxieties regarding technology often play out as anxiety about human reproduction, specifically through heteronormativity (Haraway "Promises" 299; Doane 111; Goodman xiv). Notably, though, these dramatic works not only critique traditional chauvinistic patriarchal norms of heterosexual desire, but also positively value homosexual pairings and desires. As a result, anxiety about technology arises less regarding the continued existence of the species through procreation and more about supporting broader affective relations between humans. The denouements do not reduce simply to concerns over infertility; instead they support desire itself as a social entity connecting humans. In other words, rather than a desire for reproduction, the works express concern about the reproduction of desire itself. In this way, they signal desires for connection beyond the individual as one defining a human characteristic worth supporting as new relations with technology develop.

These works by Juan Ríos, Bárbara Colio y Francisco J. López explore the recursive process defining human-technological relations. They signal elements of play and visual pleasure that, on the one hand, contribute to the democratization of desire, but, on the other, support some established hierarchies of class and masculinity. The works portray the experience of interacting with the new technologies as one of temporal disjunction and as highly linked to excessive consumerism and alienation. Further, the works focus more on the limits and exclusions of the new technologies than on the powers afforded. Their critiques of the emerging digital age do not simply defend the sujeto letrado, noting instead the continuities of literary and new 
media cultures and reflecting (on) the challenges that the recursive process of developing new human-technological relations brings. In other words, rather than reject posthumanism to retreat to an established literary humanism, the works critique emerging and established practices in order to influence them. The vision that these works offer of the borders in human-technological relations that society is crossing reflects a strong cognizance of being on one side of a border that is both permeable and violently patrolled. Rather than accept human-technological relations as set within rigid boundaries, these works characterize those relations as a process in the making, an open question to be determined.

\section{East Carolina University}

\section{Notes}

I thank Lucy Fox, Frank Romer, and Katie Ford for reading and commenting on earlier versions of this essay. I also thank the two anonymous readers for their generous critiques. I am indebted, too, to John Stevens for making possible the financial support for the trip during which I saw Generación Atari.

1 Between 1997-2004, the years in which the works were composed, interest in video and electronic technologies grew for many border authors. Elsewhere, I examine shifting attitudes of border authors toward the growing role of new media, as some saw it as threatening competition for their writing, while other, primarily younger, authors, incorporated media through Xeroxing, blogging and making online "films" ("Time"). Alejandro Madrid discusses the role of access to technology for the Nortec artists.

2 Josiah Heyman and Robert Lee Maril describe the use of various such technologies along the border zone. Claire Fox also analyzes the representations of technology as it relates to the border.

3 I thank Bárbara Colio and Juan Ríos Cantú for generously sharing with me manuscripts of their works.

${ }^{4}$ This essay forms part of a larger project examining technology and gender in Mexican creative expression. I take Haraway's term "cyborg," and N. Katherine Hayles's "posthuman" broadly as synonyms that arise from critiques of "the liberal humanist subject" (Hayles 3). Both scholars reject the idea of "essential differences or absolute demarcations between bodily existence and computer simulation, cybernetic mechanism and biological organism, robot teleology and human goals" (Hayles 3). Hayles and Clarke discuss the vital role of recursive feedback in the development of the humantechnological interactions and the resulting new subjectivities. I argue elsewhere that taking both the human and the posthuman as concepts still under construction, rather than as set entities, allows for their change and recognizes the active role that Latin American authors and their works, such as those considered here, may have in affecting those changes ("After").

5 The role of new media has not received a great deal of attention in writing on Mexican theater, though critics such as Armando Partida (Se buscan, especially 62-67 in volume 1 and 248-64 in volume 2) and Beatriz J. Rizk have analyzed the presentation of electronic technologies in the work of 
Luis Mario Moncada, who, notably, is from the northern border state of Sonora. Margarita Vargas and Nelli Florencia have analyzed another Colio play, Usted está aquí, but I am unaware of other critical treatment of the works examined here.

6 The title of the work arises from the protagonist's strange story of his grandmother's execution of cockroaches, a tale that metaphorically frames him and his lover as pests to be exterminated.

7 Jano's name, his youthful questioning of the puritanical fixation on appearances and his confronting his own urgent, inhibited desires echoes (in less heteronormative terms) the sexual dynamics that Timothy Compton sees in his analysis of Usigli's classic Jano es una muchacha.

8 Brown combines Haraway's and Hayles' ideas of humanism with those of Ángel Rama's study La ciudad letrada to form his idea of the sujeto letrado (21), which he argues Latin American authors have defended against the inevitable arrival of "el posthumanismo" (20-21, emphasis mine). By contrast, I hold that there is no singular posthumanism against which the works that I analyze react, but instead, that they critique versions of both humanism and posthumanism, for as Hayles asserts, "'human' and 'posthuman' coexist in shifting configurations that vary with historically specific contexts" (6).

9 One review of the play as performed signals the apparent difficulty for the public to understand this representation of the way the internet bridges distance with near simultaneity: "Un aspecto que no quedó claro es si la mujer está verdaderamente ahí en la habitación, viva, o se trata sólo de su espíritu, algo que únicamente por el texto quedó de manifiesto cuando 'Ella' se refiere en repetidas ocasiones a su amiga Alma y decide salir del lugar donde vive con su pareja en un intento fallido por buscarla" (Garduño Ortíz). The critic's perception of the situation as possibly a spiritual cohabitation shows that the audience's process of orientation will not always result in coherent success. It also speaks to the association of phantasmal figures and interactions with new technologies, which I comment on below.

${ }_{10}$ The image of the rootless tree also weaves in the theme of dominant social roles and the possibility of creating alternatives to such roles, which have often been seen as natural. Lila speaks of men as trees, women birds, and hopes for an alternative: "El hombre es un pájaro. Y la mujer es un árbol atado a la raíz de su raíz.... Yo soy un árbol que quiere volar" (27). At the end of the play, when she declares her own freedom as part of Jano's documentary, the rootless crown of the tree flies away.

11 Though the suicides he and his lover commit later give the quoted passage a sinister element in retrospect, I take the fatalities as an emphatic condemnation of a superficial focus on appearances more broadly, and of hypocrisy and repression toward homosexuality specifically. The protagonist savagely criticizes the dissonance of the private enjoyment of homosexual relations through videos (affirming instead that their homosexuality "es [su] realidad") and the public erasure and disapproval of this sexuality - “iLo trataste de negar!... El que me iba a enseñar el mundo, el jefe de cientos de estúpidos clasemedieros ignorantes, estaba ahí... suplicando a una mujer histérica su perdón” (85-86). He rejects the private blind of the closet.

${ }^{12}$ In her manifesto, Haraway also speaks of "the ghost in the machine" ("Cyborg" 152). However, whereas she does so to criticize a Cartesian material/spiritual binary, the spectral figures in the works register those excluded, marginalized or harmed by the role of contemporary technologies.

\section{Works Cited}

Almela, Ramón. “Asco y realidad. "Minimental Status Examination.”Critic@rte. Junio 2005. Web. 27 Aug. 2013. <http://www.criticarte.com/Page/file/ art2005/AscoYRealidadFS.html?=AscoYRealidad.html>.

Beardsell, Peter. "The Distant Centre: Perspectives of Mexico's Teatro del Norte." Bulletin of Spanish Studies 82.3-4 (2005): 427-43. Print. 
Bhabha, Homi K. The Location of Culture. New York: Routledge, 1994. Print.

Brown, J. Andrew. "Humanismo cyborg: el letrado posthumano en América Latina." Revista de crítica literaria latinoamericana 34.68 (2008): 19-32. Print.

Clarke, Bruce. Posthuman Metamorphosis: Narrative and Systems. New York: Fordham UP, 2008. Print.

Colio, Bárbara. La habitación. 2006. Manuscript.

. Teoría y práctica de la muerte de una cucaracha (sin dolor). Dramaturgia (sin dolor). Mexicali: Fondo Editorial de Baja California, 2001. Print.

Compton, Timothy G. “'Máscaras mexicanas” in Rodolfo Usigli’s Jano es una muchacha." Latin American Theatre Review 25.1 (1991): 63-71. Web. 3 December 2013. <https://kuscholarworks.ku.edu/dspace/bitstream/1808/3002/1/latr. v25.n1.063-071.pdf>.

Derrida, Jacques. Of Grammatology. Trans. Gayatri Chakravorti Spivak. Baltimore: Johns Hopkins UP, 1976. Print.

Doane, Mary Ann. "Technophilia: Technology, Representation, and the Feminine." The Gendered Cyborg: A Reader. Eds. Gil Kirkup, et al. New York: Routledge, 2000. 110-21. Print.

Fallon, Paul. "After the Posthuman, Before the Human, Questioning Both: Latin American Literature Engaging Technology." International Conference on Latin American Cybercultural Studies. University of Liverpool. May 2011. . "Time for (a Reading) Community?: The Border Literary Field in the 1980s and 1990s." Mexican Studies/Estudios Mexicanos 25.1 (2009): 47-70. Print.

Fox, Claire. The Fence and the River: Culture and Politics at the U.S.-Mexico Border. Cultural Studies of the Americas 1. Minneapolis, MN: U of Minnesota P, 1999. Print.

Galicia, Rocío. "Dramaturgia hipertextual: ensayando la frontera.” Latin American Theatre Review 45.1 (2011): 149-65. Print.

Garduño Ortíz, Edgar. "Falsas emociones de una habitación." El Milenio. March 30 2011. Web. October $1^{\text {st }} 2013$. <http://www.milenio.com/cdb/doc/impreso/8935140>.

Goodman, Robin Truth. Infertilities: Exploring Fictions of Barren Bodies. Cultural Studies of the Americas 4. Minneapolis: U Minnesota P, 2001. Print.

Gordon, Avery F. Ghostly Matters: Haunting and the Sociological Imagination. Minneapolis: U Minnesota P, 1997. Print.

Haraway, Donna. “A Cyborg Manifesto: Science, Technology, and Socialist-Feminism in the Late Twentieth Century." Simians, Cyborgs, and Women: The Reinvention of Nature. New York: Routledge, 1991. 149-81. Print.

. "The Promises of Monsters: A Regenerative Politics for Inappropriate/d Others." Cultural Studies. Eds. Lawrence Grossberg, Cary Nelson, Paula A. Treichler. New York: Routledge, 1992. 295-337. Print. 
Hayles, Katherine. How We Became Posthuman: Virtual Bodies in Cybernetics, Literature, and Informatics. Chicago: U Chicago P, 1999. Print.

Heyman, Josiah McC. "Constructing a Virtual Wall: Race and Citizenship in U.S.Mexico Border Policing." Governing Immigration through Crime: A Reader. Eds. Julie A. Dowling, and Jonathan Xavier Inda. Stanford: Stanford UP, 2013. 99-114. Print.

López, Francisco J. Cibernauta: Cómo vivir atrapado en la red. Tijuana: CAEN Editores, 1999. Print.

Madrid, Alejandro L. Nor-tec rifa!: Electronic Dance Music from Tijuana to the World. Oxford: Oxford UP, 2008. Print.

Maril, Robert Lee. The Fence: National Security, Public Safety, and Illegal Immigration along the U.S.-Mexico Border. Lubbock: Texas Tech UP, 2011. Print.

McNair, Brian. Striptease Culture: Sex, Media and the Democratization of Desire. New York: Routledge, 2002. Print.

Mijares, Enrique. La realidad virtual del teatro mexicano. México: Ediciones Casa Juan Pablos, 1999. Print.

Nelli, M. Florencia. "Usted está aquí: Antigone against the Standardization of Violence in Contemporary Mexico." Romance Quarterly 59.1 (2011): 55-65. Taylor and Francis Online. Pdf file.

Partida Tayzán, Armando. "La cultura regional: detonador de la dramaturgia del Norte." Latin American Theatre Review 36.2 (2003): 73-93. Print.

. Se buscan dramaturgos. 2 vols. México: CONACULTA; FONCA; Instituto Nacional de Bellas Artes, 2002. Print.

. "El Teatro del Norte como artefacto cultural." Gestos: teoría y práctica del teatro hispánico 48 (2009): 55-74. Print.

Quijano, Julio Alejandro. "El drama de ser dramaturgo en México". El Porvenir. 5 April 2010. Web. 28 Aug. 2013. <http://www.elporvenir.com.mx/notas. asp?nota_id $=385451>$.

Rama, Ángel. La ciudad letrada. Hanover, NJ: Ediciones del Norte, 1984. Print.

Ríos Cantú, Juan. Generación Atari. 2001-02. Manuscript.

Rizk, Beatriz J. "9 días de guerra en Facebook de Luis Mario Moncada: de cuándo el dominio privado deviene público." Latin American Theatre Review 45.2 (2011): 89-92. Print.

Trujillo Muñoz, Gabriel. La gran bonanza: Crónica del teatro en Baja California 1856-2006. Mexicali: Universidad Autónoma de Baja California, 2006. Print.

Vargas, Margarita. “The Possibility of Justice: Bárbara Colio's Antigone in Usted está aqui." Mediterranean Studies 21.1 (2013): 67-78. MUSE. Pdf file. 